\title{
Effect of the addition of cell wall degrading enzymes on fermentation kinetics of perennial ryegrass silage
}

\author{
M. A. M. RODRIGUES ${ }^{1,2}$, J. W. CONE ${ }^{2}$, C. A. SEQUEIRA ${ }^{1 *}$ \\ AND A. MASCARENHAS-FERREIRA ${ }^{1}$ \\ ${ }^{1}$ ICETA-Universidade de Trás-os-Montes e Alto Douro (UTAD), Department of Animal Nutrition, \\ Apartado 202, 5001 Vila Real Codex, Portugal \\ ${ }^{2}$ Institute for Animal Science and Health (ID-TNO), Department of Animal Nutrition, P.O. Box 65, \\ NL-8200 AB Lelystad, The Netherlands
}

(Revised MS received 25 January 2001)

\begin{abstract}
SUMMARY
Two studies were undertaken to evaluate the effects of cellulase and endoxylanase enzymes on the chemical composition and the fermentation characteristics of grass silage, using the gas production technique. Perennial ryegrass was ensiled in 1 litre glass containers for 90 days with cellulase $(0 \cdot 2 \mathrm{~g} / \mathrm{kg}$ grass on fresh weight basis) and endoxylanase in the concentrations of $0.05 \mathrm{~g} / \mathrm{kg}$ grass (Endox 0.05) and $0 \cdot 2 \mathrm{~g} / \mathrm{kg}$ grass (Endox 0.2). Subsequently, dried samples, ground through a $1 \mathrm{~mm}$ screen, were used in chemical analysis and gas production measurements. In Expt 1, the enzyme treatment significantly decreased silage $\operatorname{NDF}(P<0.001)$, ADF $(P<0.001)$ and acetic acid $(P<0.01)$ concentrations and increased lactic acid $(P<0.001)$ production. In Expt 2, lower concentrations of NDF $(P<0.001)$ and ADF $(P<0.001)$ in treated silages resulted in increased sugar concentration $(P<0 \cdot 001)$. In this experiment, butyric acid was detected. Addition of cellulase and Endox $0 \cdot 05$ enzymes did not alter silage digestibility. In both studies, cellulase and Endox $0 \cdot 2$ treatments tended to increase the rate of gas production within 10 hours of inoculation with rumen fluid whereas Endox 0.05 had no effect. The volume of gas produced was however greater for the untreated silage than for the enzyme-treated silage samples after $48 \mathrm{~h}$ of incubation. The strategy of applying cellulase and endoxylanase to the herbage in the ensiling process proved to be effective in modifying the chemical composition and increasing sugar concentration and the rate of gas production of the silages. Further research on the factors determining enzyme effectiveness is therefore suggested to elucidate the mechanisms leading to higher utilization of the released sugars.
\end{abstract}

\section{INTRODUCTION}

The mode of action of cell wall degrading enzymes during the ensiling process is the release of fermentable sugars from the structural polysaccharides which provides extra substrate for the indigenous microbial population, resulting in the production of lactic acid and consequently reducing the risk of clostridial fermentation (Van Vuuren et al. 1989). Also, the use of cell wall degrading enzymes as silage additives predigests plant cell walls which may increase the extent and rate of degradation in the rumen and, as a result, improve digestibility and nutritive value (McHan 1986). Chamberlain \& Robertson (1992) and SelmerOlsen et al. (1993a) observed decreases in NDF and ADF concentrations in grass silages due to enzyme

* To whom all correspondence should be addressed. Email: csequeir@utad.pt treatment. Enzyme treated silages are also characterized by low pH (Fredeen \& McQueen 1993; Chen et al. 1994), less acetate (Narasimhalu et al. 1992; Stokes \& Chen 1994) and increased lactic acid concentration (Stokes 1992). However, the effects of cellulolytic preparations during ensiling upon rumen fermentation are more contradictory. Although the addition of cellulolytic enzymes to the herbage has been correlated to increased amounts of organic matter digested in the rumen (McHan 1986; Chamberlain \& Robertson 1992), others have reported no significant effects of enzyme treatment (Kennedy 1988; Van Vuuren et al. 1989; Jaakkola 1990; Kung et al. 1991; Sheperd \& Kung 1996). Most of those studies have been based on time course experiments using either in sacco or in vitro techniques which measure the organic matter residue after filtration through nylon gauze, paper filter or filtering crucibles. 
Table 1. Chemical composition of the silages (Expt $1 ; \mathrm{g} / \mathrm{kg}$, unless otherwise stated)

\begin{tabular}{|c|c|c|c|c|c|c|c|c|c|c|c|c|}
\hline Treatment & $\mathrm{DM}$ & OM & $\mathrm{CP}$ & $\begin{array}{c}\text { Ammonia } \mathrm{N} \\
(\mathrm{g} / \mathrm{kg} \text { nitrogen })\end{array}$ & Sugars & NDF & $\mathrm{ADF}$ & $\mathrm{pH}$ & $\begin{array}{l}\text { Lactic } \\
\text { acid }\end{array}$ & $\begin{array}{l}\text { Acetic } \\
\text { acid }\end{array}$ & Ethanol & Digestibility \\
\hline Untreated & 249 & 870 & 150 & 98 & 20 & 414 & 252 & 4.09 & 104 & $37 \cdot 7$ & $12 \cdot 4$ & 750 \\
\hline Cellulase & 241 & 862 & 156 & 86 & 46 & 272 & 164 & $3 \cdot 80$ & 144 & $32 \cdot 3$ & $27 \cdot 4$ & 752 \\
\hline Endox 0.05 & 242 & 868 & 152 & 84 & 52 & 322 & 240 & $3 \cdot 90$ & 117 & $31 \cdot 4$ & $11 \cdot 7$ & 753 \\
\hline Endox 0.2 & 243 & 866 & 157 & 79 & 59 & 280 & 207 & 3.90 & 122 & $33 \cdot 4$ & $20 \cdot 2$ & 744 \\
\hline S.E. (4 D.F.) & $1 \cdot 1$ & $2 \cdot 5$ & 1.6 & $11 \cdot 7$ & $6 \cdot 8$ & $1 \cdot 7$ & $2 \cdot 4$ & 0.004 & $1 \cdot 4$ & $0 \cdot 64$ & $3 \cdot 43$ & $10 \cdot 6$ \\
\hline
\end{tabular}

DM, dry matter; OM, organic matter; $\mathrm{CP}$, crude protein; NDF, neutral detergent fibre; ADF, acid detergent fibre.

It has been shown that more direct information and accurate data on the kinetics of fermentation can be provided by the gas production technique, especially when an automated system is used (Pell \& Schofield 1993; Theodorou et al. 1994; Cone et al. 1996). This study investigated the efficacy of adding cell wall degrading enzymes on silage composition and rumen fermentation patterns as determined with fully automated gas production equipment (Cone et al. 1994, 1996).

\section{MATERIALS AND METHODS}

\section{Enzyme preparations}

Two different enzyme preparations, provided from Gist-brocades b.v., Delft, The Netherlands, were used: solid cellulase preparation from Trichoderma viridae (Cellulase) and Endoxylanase (Endox) with an activity of $158000 \mathrm{EXU} / \mathrm{g}$ powder, containing respectively $130 \mathrm{mg} / \mathrm{g}$ and $93 \mathrm{mg} / \mathrm{g}$ of protein (Engelen et al. 1996). The cellulase was used in a concentration of $0.2 \mathrm{~g}$ protein $/ \mathrm{kg}$ grass (fresh weight) and the endoxylanase in the concentrations of $0 \cdot 2 \mathrm{~g}$ protein $/ \mathrm{kg}$ grass (Endox 0.2) and $0.05 \mathrm{~g}$ protein/ $\mathrm{kg}$ grass (Endox 0.05). The enzyme concentration was calculated on a fresh weight basis.

\section{Silage samples}

Herbage from predominantly perennial ryegrass (Lolium perenne) swards grown in 1991 was cut at a yield of about $2000 \mathrm{~kg} / \mathrm{ha}$. The third regrowth, ensiled on 17 July, was wilted for $1 \mathrm{~h}$ on a black cloth to approximately $20 \%$ dry matter. In Expt 2, the fourth regrowth was ensiled on 14 August and shaded on the field for 6 days prior to harvesting to obtain samples with low sugar concentration. These samples, although not wilted, were ensiled at $28 \%$ dry matter. Nitrogen fertilizer was applied shortly after cutting at the rate of $30 \mathrm{~kg} \mathrm{~N} / \mathrm{ha}$, therefore totalling $150 \mathrm{~kg} \mathrm{~N} /$ ha per year.

For each treatment, duplicate $1.5 \mathrm{~kg}$ samples of herbage were chopped with a paper guillotine, to produce a chop length of $1-2 \mathrm{~cm}$, and sprayed ( $25 \mathrm{ml} / \mathrm{kg}$ herbage) with the enzyme solution with a pressure sprayer in a concrete mixer of 138 litres. The untreated herbage received water applied at the rate of $25 \mathrm{ml} / \mathrm{kg}$ herbage. Samples were treated with $0.2 \mathrm{~g}$ protein of cellulase $/ \mathrm{kg}$ herbage and 0.05 and $0.2 \mathrm{~g}$ protein of enzyme Endox $/ \mathrm{kg}$ herbage. The herbage was ensiled (in duplicate) in 1 litre laboratory silos and stored for 3 months at room temperature before opening for further analysis. Mud was also applied $(25 \mathrm{ml} / \mathrm{kg})$ to supply Clostridial spores, therefore providing a greater challenge to the silage fermentation.

\section{Sample preparation}

Silage samples were dried in an air forced oven at $70^{\circ} \mathrm{C}$ for $24 \mathrm{~h}$, ground through a $1 \mathrm{~mm}$ screen and stored in air-tight glass flasks at room temperature. For gas production measurements, the duplicate silo samples were pooled.

\section{Preparation of buffered rumen fluid $(B R F)$}

Rumen fluid was obtained from two rumen fistulated sheep kept on a daily ration of $800 \mathrm{~g}$ hay and $200 \mathrm{~g}$ commercial concentrate offered in two equal meals at 08.00 and $16.00 \mathrm{~h}$. Rumen fluid was filtered over two layers of cheese cloth. Filtered rumen fluid was mixed $(1: 2 \mathrm{v} / \mathrm{v})$ with an anaerobic buffer/mineral solution containing per litre: $8.75 \mathrm{~g} \mathrm{NaHCO}_{3}, 1.00 \mathrm{~g}$ $\mathrm{NH}_{4} \mathrm{HCO}_{3}, 1.43 \mathrm{~g} \mathrm{Na}_{2} \mathrm{HPO}_{4}, 1.55 \mathrm{~g} \mathrm{KH}_{2} \mathrm{PO}_{4}, 0.15 \mathrm{~g}$ $\mathrm{MgSO}_{4} \cdot 7 \mathrm{H}_{2} \mathrm{O}, 0.52 \mathrm{~g} \mathrm{NaS}, 0.0017 \mathrm{~g} \mathrm{CaCl} \cdot 2 \mathrm{H}_{2} \mathrm{O}$, $0.015 \mathrm{~g} \mathrm{MnCl}_{2} \cdot 4 \mathrm{H}_{2} \mathrm{O}, 0.002 \mathrm{~g} \mathrm{CoCl} \cdot 6 \mathrm{H}_{2} \mathrm{O}, 0.012 \mathrm{~g}$ $\mathrm{FeCl}_{3} \cdot 6 \mathrm{H}_{2} \mathrm{O}$ and $0 \cdot 125 \mathrm{~g}$ resazurin (Beuvink \& Spoelstra 1992). All handling was done under continuous flushing with oxygen-free $\mathrm{CO}_{2}$.

\section{Determination of gas production kinetics}

Gas production upon incubation of samples with buffered rumen fluid was monitored for $48 \mathrm{~h}$ as described by Cone et al. (1996). Samples were 
incubated in duplicate in two separate series performed on different days. In each series, a blank (rumen fluid without sample) was run in duplicate.

\section{Chemical analyses}

Silage $\mathrm{pH}$ and concentrations of ethanol, lactic acid, acetic acid and butyric acid were determined in the aqueous silage extract. Ethanol, lactic acid, acetic acid and butyric acid concentrations were determined by gas chromatography from a $4 \mathrm{ml}$ sample of centrifuged $(20 \mathrm{~min}$ at $8000 \mathrm{~g})$ extract preserved with $0.8 \mathrm{ml}$ of a $5 \%$ phosphoric acid solution. Lactic acid concentration in centrifuged extracts was determined as acetaldehyde by gas chromatography. The concentrations of oven-dry matter, ash, crude protein and sugars were determined by routine methods (Spoelstra 1983). Ammonia was estimated in a centrifuged extract preserved with $1 \mathrm{ml} 1 \mathrm{~N}_{2} \mathrm{SO}_{4}$ per $\mathrm{ml}$ and stored at $-24{ }^{\circ} \mathrm{C}$ until analysis according to a modified Bertholet method (Searle 1984) on an autoanalyser. Neutral detergent fibre (NDF) and acid detergent fibre (ADF) were determined according to Robertson \& Van Soest (1981). The in vitro organic matter digestibility was measured by the Tilley \& Terry (1963) method.

Dry matter was corrected for loss of volatile fermentation products assuming that ethanol, acetic acid, propionic acid and butyric acid were completely volatilized during oven drying. All of the silage components were expressed on this corrected dry matter basis.

\section{Statistical procedures}

The effect of the addition of enzymes and the influence of ensiling conditions (stage of maturity) on silage composition and total gas production was determined by Fisher's Protected LSD analysis (Wilkinson et al. 1996).

\section{RESULTS}

The chemical composition of the silages of the first and second studies is presented in Tables 1 and 2, respectively. Enzyme treatment decreased $\mathrm{pH}$ $(P<0.001)$ and the concentrations of DM $(P<0.05)$, NDF $(P<0.001)$, ADF $(P<0.001)$ and acetic acid $(P<0.01)$ and increased the concentrations of lactic acid $(P<0.001)$ and crude protein $(P<0.05)$. Cellulase increased ethanol concentration $(P<0.05)$ whereas Endox 0.05 and 0.2 had no effect $(P>0 \cdot 05)$. Enzyme treatment had no effect $(P>0.05)$ on the sugar concentration or digestibility relative to the untreated silage.

The untreated silage in the second study was well preserved as measured by $\mathrm{pH}$ and the concentration of ammonia nitrogen. Treatment with enzymes decreased the concentrations of NDF $(P<0.001)$ and

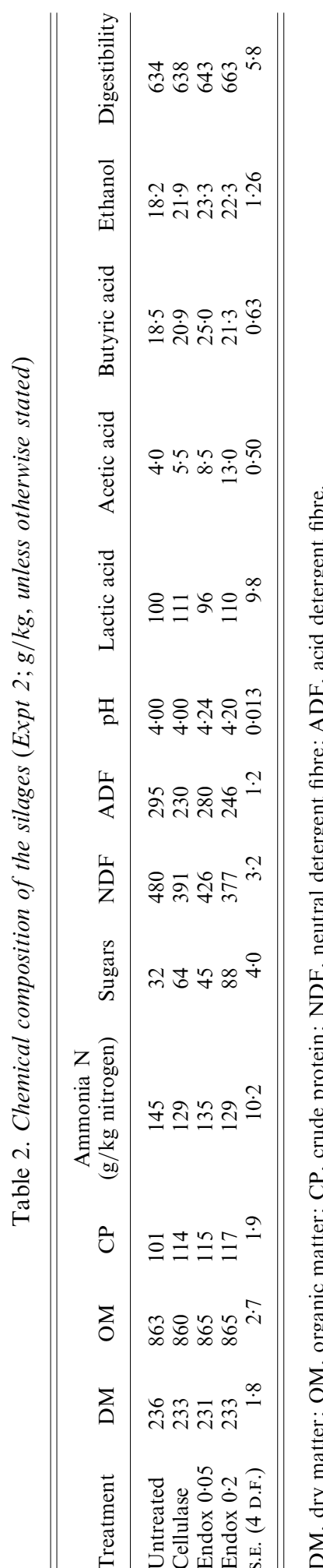




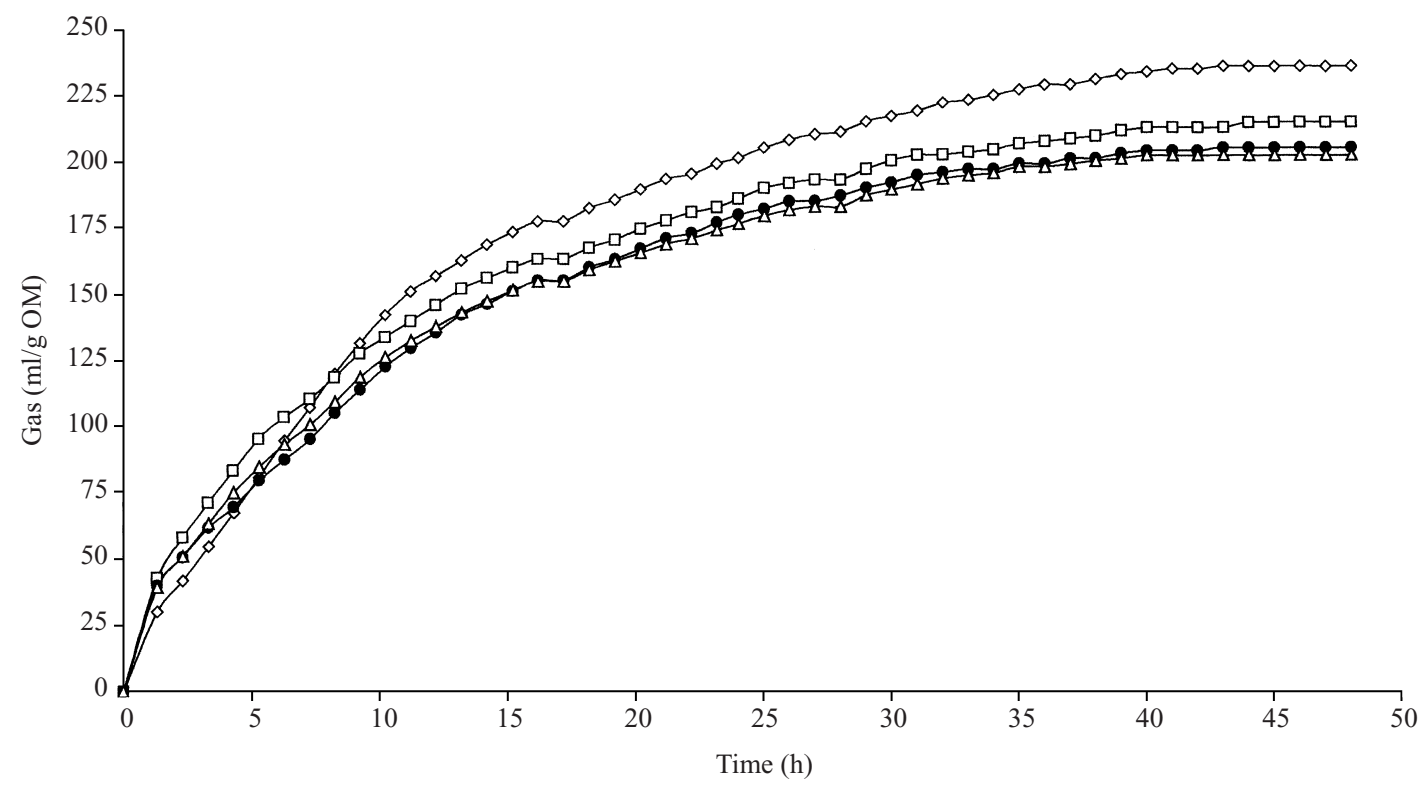

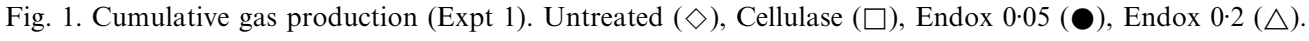

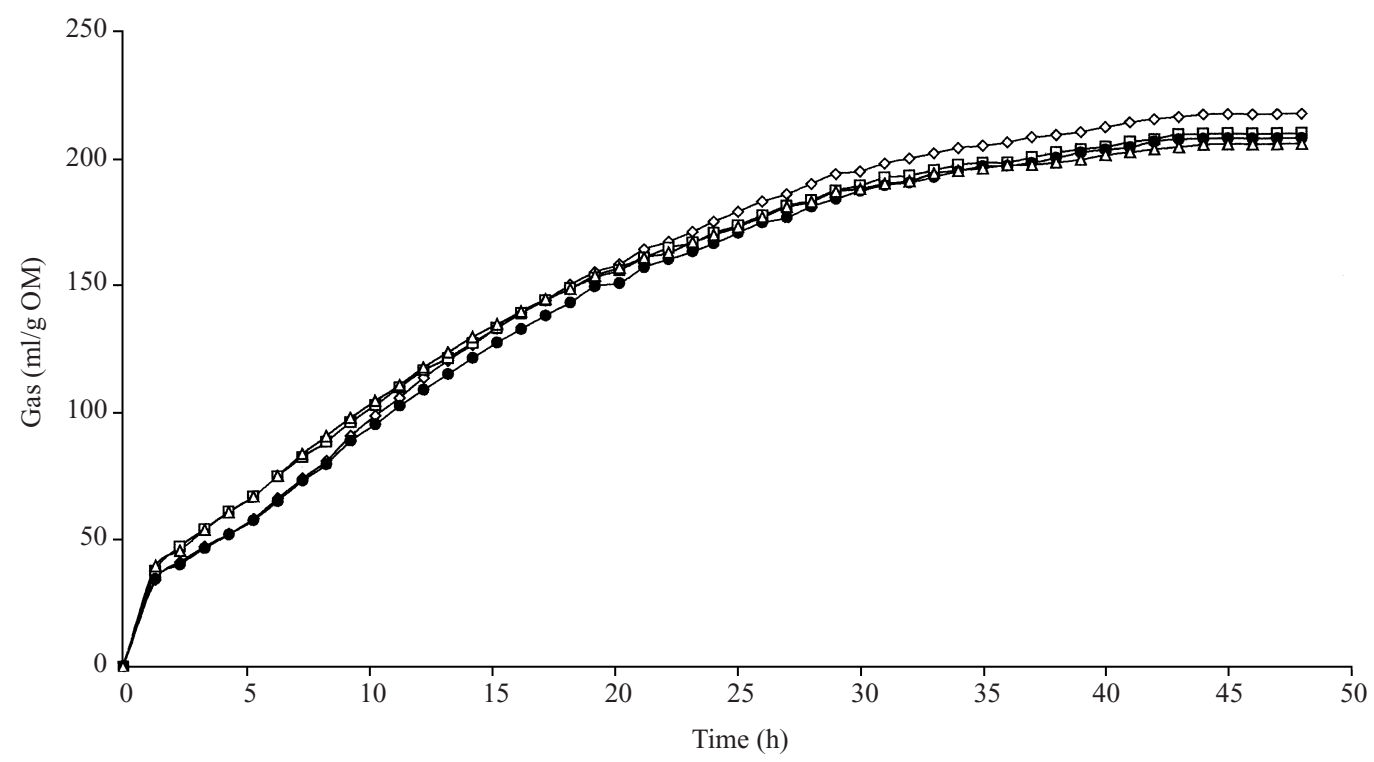

Fig. 2. Cumulative gas production (Expt 2). Untreated $(\diamond)$, Cellulase ( $\square)$, Endox 0.05 (๑), Endox 0·2 ( $\triangle$ ).

ADF $(P<0 \cdot 001)$. Relative to the untreated silage, Endox 0.05 and 0.2 treatments increased $\mathrm{pH}$ $(P<0.001)$ and concentrations of acetic acid $(P<0 \cdot 001)$ and butyric acid $(P<0 \cdot 01)$. Cellulase and Endox 0.2 increased sugar concentrations $(P<0.01)$ whereas Endox 0.05 had no effect $(P>0.05)$. Endox $0 \cdot 2$ increased digestibility relative to the untreated silage whereas cellulase and Endox 0.05 had no effect
$(P>0 \cdot 05)$. Treatment had no effect $(P>0 \cdot 05)$ on the concentrations of dry matter, organic matter, crude protein, ammonia $\mathrm{N}$, lactic acid and ethanol.

The effects of treatment on cumulative gas production for Expts 1 and 2 are presented in Figs 1 and 2 , respectively. In the first experiment, after $8-10 \mathrm{~h}$ of fermentation, the volume of gas produced was greater for the untreated silage than for the enzyme-treated 


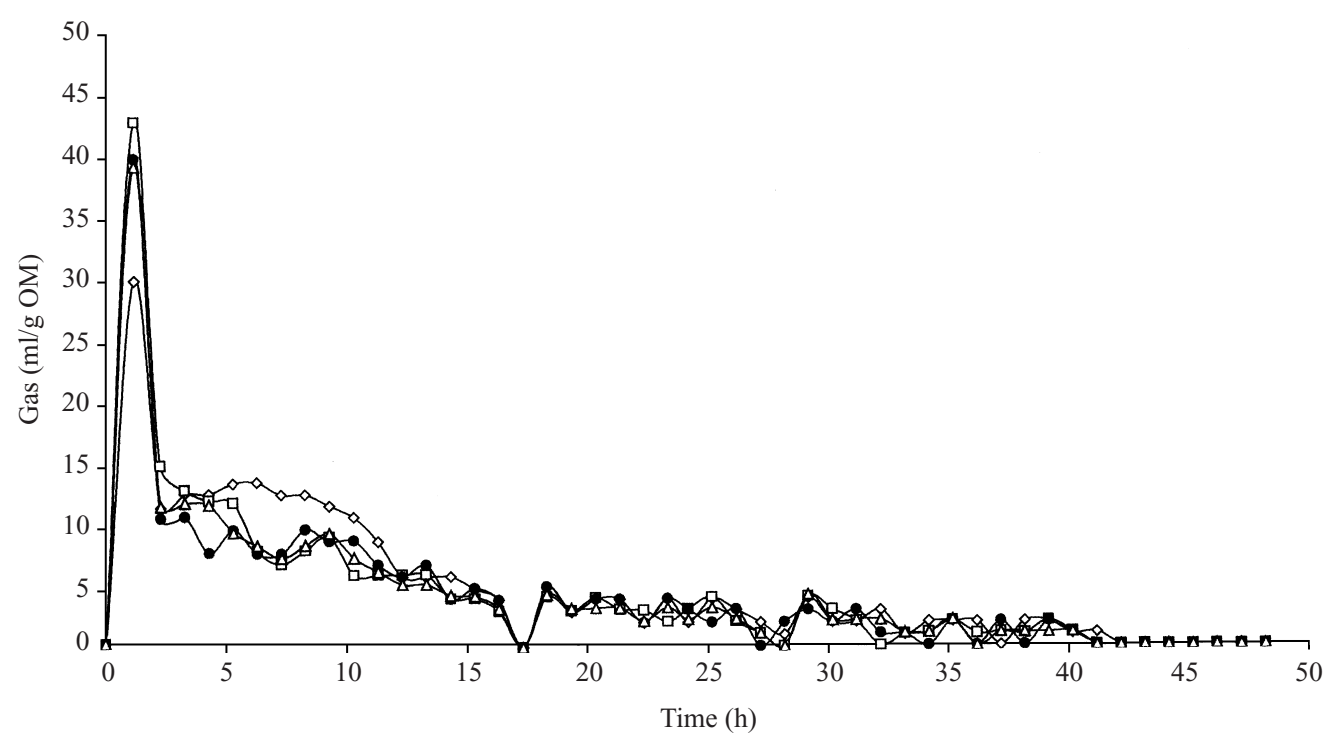

Fig. 3. Rate of gas production (Expt 1). Untreated $(\diamond)$, Cellulase $(\square)$, Endox $0 \cdot 05(\bullet)$, Endox $0 \cdot 2(\triangle)$.



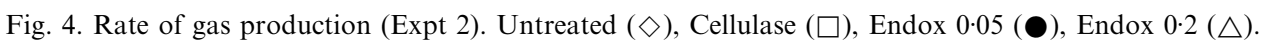

silage samples. Among the studied enzymes, the cellulase was the most effective leading to higher gas production during the whole fermentation procedure. However, in Expt 2, the gas production profiles were similar for the different substrates.

The effects of treatment on the rate of gas production in Expts 1 and 2 are presented in Figs 3 and 4 , respectively. In both studies gas production reached a peak after $1-2 \mathrm{~h}$ with the untreated silage producing the lowest peak in both studies. Treating the herbage with enzyme tends to increase the rate of gas production within $10 \mathrm{~h}$ of inoculation with rumen fluid. This effect was, however, less evident in Expt 2.

\section{DISCUSSION}

In this study, the addition of cell wall degrading enzymes during the ensiling process induced differences between the chemical composition of treated and untreated ryegrass silage. As shown in 
Tables 1 and 2, cellulase and endoxylanase mainly modified the concentration in cell wall components. While decreasing NDF and ADF in both experiments, the enzyme treatment was more effective in Expt 1, dealing with less mature ryegrass. These observations, which are in agreement with those of Beuvink \& Spoelstra (1994) and Adogla-Bess \& Owen (1995a,b), should be viewed as a result of the increase in ligninpolysaccharide complexes of plant cell walls which are refractory to enzyme hydrolysis. The increased production of lactic acid due to the enzyme treatment, as observed in Expt 1, as well as the appearance of butyric acid in Expt 2 also support that hypothesis. Notwithstanding the general increase in sugar concentration of the treated silages, it should therefore be assumed that lignification and higher lignification rate occurring in mature forages become the major constraint to the efficacy of the cell wall degrading enzymes in the ensiling process.

Differences between the gas production profiles of treated and untreated ryegrass silage were also observed. Although it has been shown that enzyme treatment favourably modifies the chemical composition of silages, the observed gas production profiles did not reflect this mode of action. Despite the tendency for higher rates of production when treated silages were the substrate, especially from less mature herbage, the total amount of gas produced did not reach the values observed in untreated samples. It seems unlikely that the extra sugars released by the action of cellulase and endoxylanase would have been completely available to microbial fermentation. McHan (1986), Van Vuuren et al. (1989), Jaakkola et al. (1992) and Selmer-Olsen et al. (1993a,b) showed an increase in the concentration of soluble cell wall fractions of the grass silage after enzyme treatment, but it is also recognized that the effectiveness of enzyme treatment is dependent on factors including plant species, maturity, chemical composition and ensiling conditions.

In our study, the efficacy of the enzyme treatments appeared to be reduced. This may also be a plausible explanation for our data not supporting the expected positive correlation between digestibility and enzyme addition in the ensiling process. These findings have also been reported by Adogla-Bess \& Owen (1995b), Jaakkola (1990) and Jaakkola et al. (1992). However, applying cellulase and endoxylanase to the herbage in the ensiling process proved to be a valuable strategy for increasing sugar concentration and the rate of gas production of the silages. Since the gas production method has proved to be accurate and also allows the measurement of fermentation kinetics of soluble substrates, more research into the evaluation of factors determining enzyme efficacy would be helpful in elucidating the mechanisms leading to higher utilization of released sugars.

The authors are grateful to Ton Van Gelder, Piet Van Wikselaar and Frank Driehuis for technical support, valuable discussions and suggestions, and to Gist-brocades b.v. for providing the enzymes.

\section{REFERENCES}

Adogla-Bess, T. \& Owen, E. (1995a). Ensiling of wholecrop wheat with cellulase-hemicellulase based enzymes. 1 . Effect of crop growth stage and enzyme on silage composition and stability. Animal Feed Science and Technology 55, 335-347.

Adogla-Bess, T. \& Owen, E. (1995b). Ensiling of wholecrop wheat with cellulase-hemicellulase based enzymes. 2 . Effect of crop growth stage and enzyme on silage intake, digestibility and live-weight gain by steers. Animal Feed Science and Technology 55, 349-357.

Beuvink, J. M. W. \& Spoelstra, S. F. (1992). Interactions between substrate, fermentation end-products, buffering systems and gas production upon fermentation of different carbohydrates by mixed rumen microorganisms in vitro. Applied Microbiology and Biotechnology 37, 505-509.

Beuvink, J. M. W. \& Spoelstra, S. F. (1994). In vitro gas production kinetics of grass silages treated with different cell-wall degrading enzymes. Grass and Forage Science 49, 277-283.

Chamberlain, D. G. \& Robertson, S. (1992). The effects of the addition of various enzyme mixtures on the fermentation of perennial ryegrass silage and on its nutritional value for milk production in dairy cows. Animal Feed Science and Technology 37, 257-264.

Chen, J., Stokes, M. R. \& Wallace, C. R. (1994). Effects of enzyme-inoculant systems on preservation and nutritive value of haycrop and corn silages. Journal of Dairy Science 77, 501-512.

Cone, J. W., Beuvink, J. M. W. \& Rodrigues, M. (1994). Use and application of an automated time related gas production test for the in vitro study of fermentation kinetics in the rumen. Revista Portuguesa de Zootecnia 1, $25-37$.

Cone, J. W., Van Gelder, A. H., Visscher, G. J. W. \& OUdSHOORN, L. (1996). Influence of rumen fluid and substrate concentration on fermentation kinetics measured with a fully automated time related gas production apparatus. Animal Feed Science and Technology 61, $113-128$.

Engelen, A. J., Van Der Heeft, F. C. \& Ransdorp, P. H. G. (1996). Viscosimetric determination of betaglucanase and endoxylanase activity in feed. Journal of AOAC International 79, 1019-1025.

FredeEN, A. H. \& MCQueEN, R. E. (1993). Effect of enzyme additives on quality of alfalfa/grass silage and dairy cow performance. Canadian Journal of Animal Science 73, 581-591.

JAAKKOLA, S. (1990). The effect of cell wall degrading enzymes on the preservation of grass and on the silage intake and digestibility in sheep. Journal of Agricultural Science in Finland 62, 51-62.

JaAkkola, S., Huhtanen, P. \& Hissa, K. (1992). The effect 
of cell wall degrading enzymes or formic acid on fermentation quality and digestion of grass silage by cattle. Grass and Forage Science 46, 75-81.

Kennedy, S. J. (1988). The effect of an enzyme additive on the preservation and nutritive value of grass silage fed to beef cattle. In Proceedings of the Eighth AFRC Silage Conference, pp. 25-26. Hurley, UK: IGAP.

Kung, L. JR., Tung, R. S., Maciorowski, K. G., Buffum, K., KNutsen, K. \& Aimutis, W. R. (1991). Effects of plant cell wall degrading enzymes and lactic acid bacteria on silage fermentation and composition. Journal of Dairy Science 74, 4284- 4296.

McHan, F. (1986). Cellulase-treated Coastal Bermudagrass silage and production of soluble carbohydrates, silage acids and digestibility. Journal of Dairy Science 69, 431-438.

Narasimhalu, P., Halliday, L. J., Sanderson, J. B., Kunelius, H. T. \& Winter, K. A. (1992). The composition, intake, and digestibility of timothy silage preserved untreated or treated with formic acid or a cellulase-hemicellulase preparation. Canadian Journal of Animal Science 72, 431-434.

Pell, A. N. \& Schofield, P. (1993). Computerized monitoring of gas production to measure forage digestion in vitro. Journal of Dairy Science 76, 1063-1073.

Robertson, J. B. \& Van Soest, P. (1981). The detergent system of analysis and its application to human foods. In The Analysis of Dietary Fibre in Food (Eds T. James \& O. Theander), pp. 123-158. New York: Marcel Dekker.

Searle, P. L. (1984). The Bertholet or indophenol reaction and its use in the analytical chemistry on nitrogen. A review. The Analyst 109, 549-568.

Selmer-Olsen, I., Henderson, A. R., Robertson, S. \& McGinn, S. (1993a). Cell wall degrading enzymes for silage. I. The fermentation of enzyme-treated ryegrass in laboratory silos. Grass and Forage Science 48, 45-54.

Selmer-Olsen, i., Henderson, A. R., Robertson, S. \& MCGINN, S. (1993b). Cell wall degrading enzymes for silage. II. Aerobic stability of enzyme-treated laboratory silages. Grass and Forage Science 48, 55-63.

ShePerd, A. C. \& Kung, L. JR. (1996). An enzyme additive for corn silage: effects on silage composition and animal performance. Journal of Dairy Science 79, 1760-1766.

SPOELSTRA, S. F. (1983). Inhibition of clostridial growth by nitrate during the early phase of silage fermentation. Journal of the Science of Food and Agriculture 34, 145-152.

Stokes, M. R. (1992). Effects of an enzyme mixture, an inoculant, and their interaction on silage fermentation and dairy production. Journal of Dairy Science 75, 764-773.

Stokes, M. R. \& Chen, J. (1994). Effects of an enzymeinoculant mixture on the course of fermentation and dairy production. Journal of Dairy Science 77, 3401-3409.

Theodorou, M. K., Williams, B. A., Dhanoa, M. S., McAllan, A. B. \& France, J. (1994). A simple gas production method using a pressure transducer to determine the fermentation kinetics of ruminant feeds. Animal Feed Science and Technology 48, 185-197.

Tilley, J. M. A. \& Terry, R. A. (1963). A two stage technique for the in vitro digestion of forage crops. Journal of British Grassland Society 18, 104-111.

Van Vuuren, A. M., Bergsma, K., Krol-Kramer, F. \& VAN BEERS, J. A. C. (1989). Effects of addition of cell wall degrading enzymes on the chemical composition and the in sacco degradation of grass silage. Grass and Forage Science 44, 223-230.

Wilkinson, L., Hill, M., Welna, J. P. \& Birkenbeuel, G. K. (1992). Systat for Windows: Statistics, 5th Edn. Evanston, IL: SYSTAT Inc. 